\title{
Respiratory and Allergic Effects in Children Exposed to Pesticides-A Systematic Review
}

\author{
Rafael Junqueira Buralli ${ }^{1,2, * \mathbb{C}}$, Amana Freitas Dultra ${ }^{1}$ and Helena Ribeiro ${ }^{1}$ (D) \\ 1 Departamento de Saúde Ambiental, Faculdade de Saúde Pública, Universidade de São Paulo, \\ São Paulo-SP 01246-904, Brazil; amanadultra@gmail.com (A.F.D.); lena@usp.br (H.R.) \\ 2 Department of Environmental and Occupational Health and Public Health Emergency Surveillance, \\ Brazilian Ministry of Health (DSASTE/SVS/MS), Brasília-DF 70723-040, Brazil \\ * Correspondence: rafael.buralli@saude.gov.br; Tel.: +55-11-3061-7894
}

Received: 5 March 2020; Accepted: 2 April 2020; Published: 16 April 2020

\begin{abstract}
Pesticide exposure may affect children's respiratory and allergic health, although results from epidemiological studies have not reached consensus. This review aims to analyze the scientific evidence on respiratory and allergic effects of exposure to agricultural pesticides in children aged up to 12 years old. The databases PubMed, Web of Science, Scielo, and Lilacs were screened to select articles published in English, Spanish, or Portuguese, and 21 articles were included in this review. Most investigations were conducted in North America (mostly in the United States), while no studies conducted in Latin America or Africa were found, despite their intensive use of pesticides. Children are exposed to pesticides through multiple pathways from the prenatal period throughout later developmental stages and may experience several respiratory effects. Most studies (79\%) found positive associations with pesticide exposure and children's respiratory and allergic effects such as asthma, wheezing, coughs, acute respiratory infections, hay fever, rhinitis, eczema, chronic phlegm, and lung function impairments. Contrastingly, $21 \%$ of the studies found no associations between pesticide exposure and children's respiratory health. The vast differences among the characteristics of the studies hamper any comparison of the results. Exposure to pesticides may have several impacts on childhood respiratory health. More studies must be conducted, especially in low- and middle-income countries, preferably with comparable research protocols adapted to local realities. Efforts should be made to develop comprehensive risk mitigation strategies and behavioral interventions to reduce children's exposure to pesticides used in agriculture and respiratory health effects, and to ensure healthy childhood growth.
\end{abstract}

Keywords: pesticide; child; lung function; respiratory symptoms; allergy

\section{Introduction}

Epidemiological studies with adults suggest that occupational exposure to pesticides is associated with a higher prevalence of respiratory symptoms [1,2], asthma and allergies [3,4], and changes in lung function $[1,2,5-7]$. These findings were also reinforced by two literature reviews recently published [8,9]. However, little is known about the effects of exposure to pesticides used in agriculture on childhood respiratory health.

Children of farmers are at risk of pesticide exposure for multiple reasons, including: living close to agricultural fields; engaging in farm work from an early age; eating fruits and vegetables directly from the fields or soon after harvest; facing "take-home" exposure from farmworkers in their homes; being exposed during pesticide use at home for pest control [10,11]; and accidents with chemicals. Other factors may influence childhood exposure to pesticides, such as the mother's exposure during pregnancy, time spent on the floor in areas of pesticide deposition, hand-to-mouth habits, 
and having diets often based on foods with a higher concentration of residues (e.g., fruits, juices and milk) $[9,10,12]$. Furthermore, children eat, drink and breathe more in proportion to personal weight than adults [10], have greater physiological susceptibility during development [13], and have a lower ability to metabolize and eliminate chemicals [14].

Few studies have examined associations between childhood exposure to pesticides and respiratory health, and the studies that have been carried out have not reached consensus. Maternal reporting of general pesticide exposure was associated with increased reports of chronic respiratory symptoms among school-aged children in Lebanon [15]. A case-control study found that children with reported pesticide exposure in the first year of life had 2.4 times the odds of developing asthma compared to those with no exposure [16]. Residential use of pesticides was weakly associated with respiratory symptoms among children under 18 years of age in the U.S. National Health and Nutrition Examination Survey (NHANES) [17]. However, a study in the Netherlands found no association between living near agricultural fields likely to be treated with pesticides and asthma and related respiratory symptoms [18].

Only restricted studies have examined the effects of specific pesticides on children's respiratory health. Higher exposure to organophosphate pesticides (OP) during pregnancy and childhood (from birth to age five) were associated with increased odds of respiratory symptoms at age seven [19], and higher phosphate metabolites (diethyl and dimethyl) in childhood were associated with decreased lung function at seven years of age [20] among the children of farmworkers from California. Contrastingly, a cross-sectional study in NHANES found no associations of urinary OP metabolites (dialkyl phosphate and serum dichlorodiphenyldichloroethylene), and asthma risk [21]. A birth cohort study assessed pesticide exposure through personal air samples, and found that higher prenatal measurements of the pyrethroids cis-permethrin, but not trans-permethrin, were associated with increased cough symptoms in children by age five [22].

In order to verify the state of established knowledge regarding this important issue, a systematic review was undertaken to gather the published scientific evidence on the respiratory and allergic effects of children's exposure to pesticides used in agriculture.

\section{Materials and Methods}

This systematic review was conducted in accordance with the Preferred Reporting Items for Systematic Review and Meta-Analysis (PRISMA) process to identify published scientific evidence about respiratory and allergic effects in children exposed to agricultural pesticides. The PECO framework was used to delineate this review based on: (a) population: children up to 12 years old; (b) exposure: pesticides of all classes and types of use; (c) comparison: without the restriction of comparator groups (e.g., children not exposed to pesticides or exposed to different intensities and sources); (d) outcomes: All respiratory morbidities (e.g., symptoms, asthma, obstructive diseases) and lung function impairments.

The databases PubMed (www.ncbi.nlm.nih.gov/pubmed/), Web of Science (www.isiknowledge. com), Scielo (search.scielo.org), and Lilacs (pesquisa.bvsalud.org/portal/advanced/) were consulted to select articles in English, Spanish, or Portuguese using the following terms: For English: (pesticid* OR agrochemic $^{*}$ OR fumigant ${ }^{*}$ OR fungicide* OR insecticide* OR herbicide* OR acaricide ${ }^{*}$ OR nematicide*) AND (child* OR pregnan* OR prenatal OR offspring OR newborn OR early-life OR infant* OR


For Spanish and Portuguese: (pesticid* OR plaguicida* OR agrotoxico* OR agroquimic* OR fumigant* OR fungicida* OR inseticida* OR insecticida* OR herbicida* OR acaricida* OR nematicida*) AND (niñ ${ }^{*}$ OR criança* OR emabaraz* OR gravid* OR gesta* OR prenatal* OR pré-natal* OR hij* OR filh* OR nascid $^{*}$ OR infant* OR escolar ${ }^{*}$ ) AND (respirat* OR pulmon* OR asma* OR alerg* OR hipersensitivit* OR rinit*). 
The search on PubMed was conducted by the title, abstract, and MeSH terms; the search on Web of Science included topic (title, abstract and keywords); the search on Scielo included all indexes; and the search on Lilacs included all words. No temporal filter was established, and articles published until September 2019 were included in this review.

Only articles with full text available were included; and review, meta-analysis, experimental, qualitative and case studies were excluded. Articles focused exclusively on residential exposure to pesticides, and house allergens such as dust, cats, dogs, mites and cockroaches were also excluded. In the first screening, two independent reviewers read the article's title, and selected those focusing on pesticide for agricultural use, being as inclusive as possible. In this screening, 163 articles were selected for the screening phase, and three reviewers independently read all abstracts to select relevant papers regarding the association of childhood respiratory health and agricultural pesticides. At this point, 136 articles were excluded because they did not meet the inclusion criteria or deal directly with the issue investigated. In case of disagreement, the three reviewers decided together what to do. Articles about respiratory and allergic effects of pesticide exposure in children from all ethnic groups, geographical location, and socioeconomic status were selected. Furthermore, each of the remaining 27 articles were fully read by at least two reviewers to gather the relevant information. Finally, the data extracted from the selected articles were checked for consistency by two reviewers.

After reading the full-text of articles considered eligible (27), six manuscripts were excluded for the following reasons: exposure study without addressing health effects; study on residential exposure to pesticides; study about house dust mite allergens; study with adults as subjects; and hospital-based studies which addressed differences between rural and urban populations; and children's clinical course after pesticide poisoning without focusing on respiratory effects. Thus, 21 articles were finally selected and are discussed in this review (Figure 1).

The remaining selected articles were organized by the study location, design and year of publication, sample size and age, types of pesticides, exposure pathway and activity, exposure assessment method, period of exposure, health effect and assessment method, and main findings. These data were discussed, and study results compared, considering the prevalence, risk ratios, and odds ratios of health outcomes. 


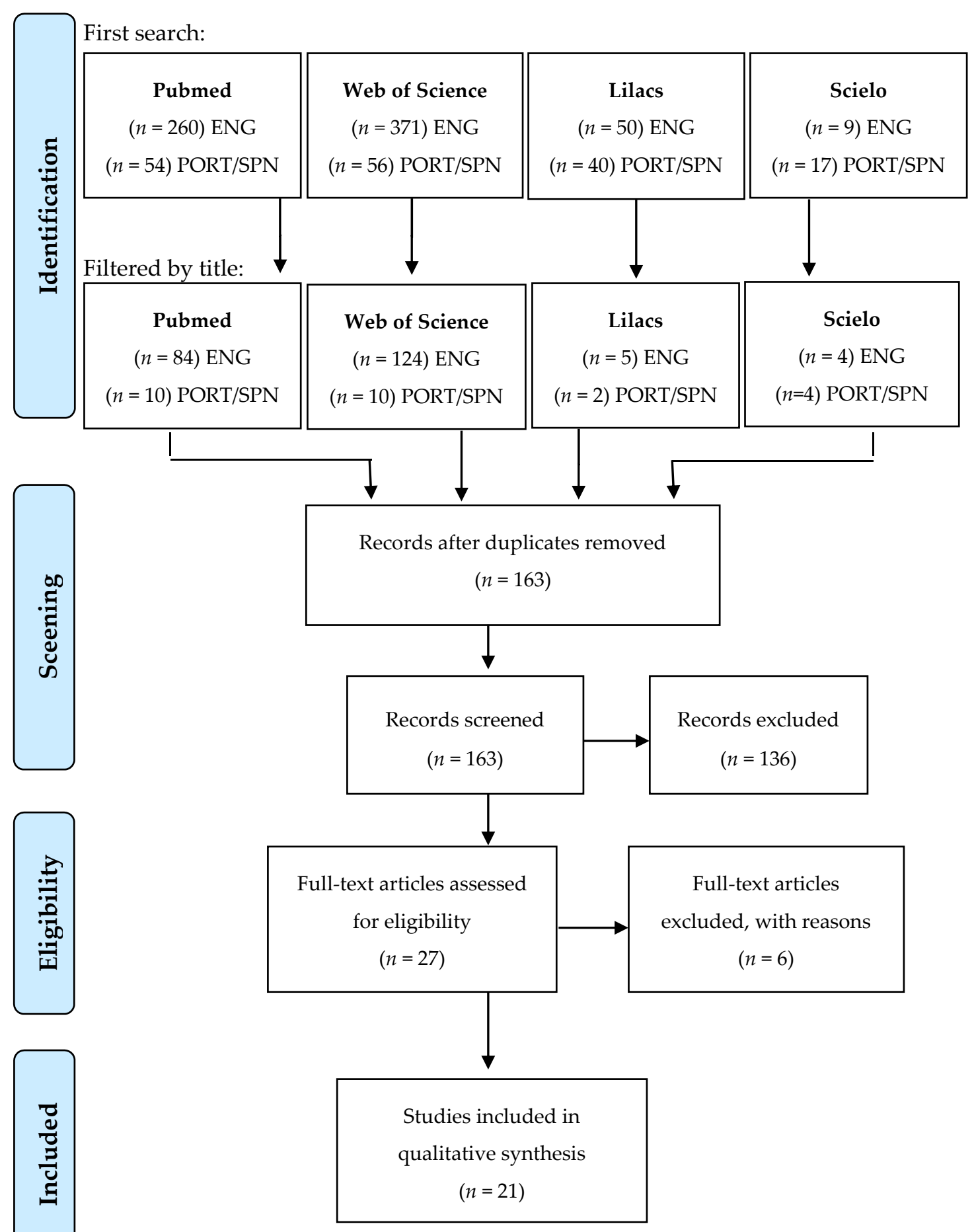

Figure 1. Flow chart of study selection.

\section{Results and Discussion}

The studies included in this review are displayed in Tables 1-3, divided by the classes of pesticides assessed. Articles were separated in OP, OC, and multiple pesticides without assessing health effects separately (presented in Tables 1-3, respectively) because of their potential differences in characteristics, toxicity, and health effects on humans. 
Table 1. Studies on respiratory and allergic effects of organophosphate pesticides (OP) in children.

\begin{tabular}{|c|c|c|c|c|c|c|c|c|}
\hline $\begin{array}{l}\text { Author, Year } \\
\text { and Country }\end{array}$ & Study Design & Study Sample & $\begin{array}{l}\text { Pesticides } \\
\text { Addressed }\end{array}$ & $\begin{array}{l}\text { Exposure Pathway and } \\
\text { Activity }\end{array}$ & $\begin{array}{l}\text { Exposure Assessment } \\
\text { Method }\end{array}$ & Period of Exposure & $\begin{array}{l}\text { Health Effect and } \\
\text { Assessment Method }\end{array}$ & Results \\
\hline $\begin{array}{l}\text { Duramad, P. et } \\
\text { al. 2006/USA }\end{array}$ & $\begin{array}{c}\text { Longitudinal } \\
\text { birth cohort } \\
\text { (CHAMACOS) }\end{array}$ & $\begin{array}{l}412 \text { children } \\
\text { aged up to } 24 \\
\text { months }\end{array}$ & $\mathrm{OP}$ & $\begin{array}{l}\text { Children who reside in } \\
\text { agricultural settings }\end{array}$ & $\begin{array}{l}\text { Questionnaire-based } \\
\text { interviews with home visits }\end{array}$ & Prenatal up to 24 months & $\begin{array}{l}\text { Respiratory symptoms } \\
\text { through } \\
\text { questionnaire-based } \\
\text { interviews, medical } \\
\text { records, and Th1 and Th2 } \\
\text { cytokines as biomarkers of } \\
\text { allergic asthma. }\end{array}$ & $\begin{array}{l}\text { Asthma and wheeze outcomes in } \\
\text { children at } 24 \text { months of age were } \\
\text { associated with elevated Th2 status in } \\
\text { children at early age. }\end{array}$ \\
\hline $\begin{array}{l}\text { Raanan, R. et al. } \\
\text { 2015/USA }\end{array}$ & $\begin{array}{c}\text { Longitudinal } \\
\text { birth cohort } \\
\text { (CHAMACOS) }\end{array}$ & $\begin{array}{l}364 \text { children } \\
\text { aged } 5 y \text { and } 7 y\end{array}$ & $\mathrm{OP}$ & $\begin{array}{l}\text { At least } 1 \text { agriculture } \\
\text { worker in household }\end{array}$ & $\begin{array}{l}\text { Maternal interviews and } \\
\text { urinary DAP }\end{array}$ & $\begin{array}{l}\text { Prenatal and childhood } \\
\text { until age 5y and 7y }\end{array}$ & $\begin{array}{l}\text { Respiratory symptoms } \\
\text { through questionnaire } \\
\text { (ISAAC) }\end{array}$ & $\begin{array}{l}\text { Higher prenatal and childhood DAP [] } \\
\text { were non-significantly associated with } \\
\text { respiratory symptoms at 5y and 7y. }\end{array}$ \\
\hline $\begin{array}{l}\text { Raanan, R. et al. } \\
\text { 2016/USA }\end{array}$ & $\begin{array}{l}\text { Longitudinal } \\
\text { birth cohort } \\
\text { (CHAMACOS) }\end{array}$ & $\begin{array}{l}279 \text { children } \\
\text { aged } 7 y\end{array}$ & $\mathrm{OP}$ & $\begin{array}{l}\text { At least } 1 \text { agriculture } \\
\text { worker in household }\end{array}$ & $\begin{array}{l}\text { Maternal interviews, home } \\
\text { visits, six urinary DAP } \\
\text { measured during pregnancy } \\
\text { and five times in childhood }\end{array}$ & $\begin{array}{c}\text { Prenatal and childhood } \\
\text { until 7y }\end{array}$ & Spirometry & $\begin{array}{l}\text { Childhood diethyl, dimethyl and total } \\
\text { DAP [] were associated with } \\
\text { significant decreases in lung function } \\
\text { at age 7. Significantly lower } \mathrm{FEV}_{1}(\mathbb{B}= \\
-0.16,95 \% \mathrm{CI}-0.30 ;-0.02) \text {, and FVC } \\
(\mathbb{B}=-0.17,95 \% \text { CI: }-0.34 ; 0.01) \text { were } \\
\text { observed per 10-fold increase of } \\
\text { children's total DAP levels. }\end{array}$ \\
\hline $\begin{array}{l}\text { Benka-Coker, } \\
\text { WO. et al. } \\
\text { 2019a/USA }\end{array}$ & $\begin{array}{l}\text { Longitudinal } \\
\text { cohort with } 4 \\
\text { months } \\
\text { follow-up }\end{array}$ & $\begin{array}{l}16 \text { asthmatic } \\
\text { children aged } 6 \\
\text { to } 16 y \text { from } \\
\text { agricultural } \\
\text { communities }\end{array}$ & $\begin{array}{l}\text { OP and joint } \\
\text { effects with } \\
\text { PM2.5 and } \\
\text { Ozone }\end{array}$ & $\begin{array}{l}\text { Residential proximity to } \\
\text { crop areas, and parents } \\
\text { involvement in agriculture }\end{array}$ & $\begin{array}{l}\text { Repetitive urine samples for } \\
\text { DAP (summative measures), } \\
\text { and PM2.5 and Ozone [] data } \\
\text { from local monitoring stations }\end{array}$ & Not clear & $\begin{array}{l}\text { Asthma assessed through } \\
\text { urinary uLTE4 collected } \\
\text { every } 6 \text { days during the } \\
\text { study period }\end{array}$ & $\begin{array}{l}\text { Higher exposures to OP were } \\
\text { associated with increases in the LTE4 } \\
\text { levels, and concurrent short-term } \\
\text { exposure to PM } 2.5 \text { was associated } \\
\text { with an increase in a marker of asthma } \\
\text { morbidity. }\end{array}$ \\
\hline $\begin{array}{l}\text { Benka-Coker, } \\
\text { WO. et al. } \\
\text { 2019b/USA }\end{array}$ & $\begin{array}{l}\text { Longitudinal } \\
\text { cohort with } 4 \\
\text { months } \\
\text { follow-up }\end{array}$ & $\begin{array}{l}16 \text { asthmatic } \\
\text { children aged } \\
6-16 y \text { from } \\
\text { agricultural } \\
\text { communities }\end{array}$ & $\mathrm{OP}$ & $\begin{array}{l}\text { Residential proximity to } \\
\text { crop areas, and parents' } \\
\text { involvement in agriculture }\end{array}$ & $\begin{array}{l}\text { Repetitive urine samples for } \\
\text { DAP, and comparison with } \\
\text { another population-based } \\
\text { cohort (NHANES). The total } \\
\text { OP exposure was estimated } \\
\text { through summative DAP } \\
\text { measures, rather than } \\
\text { individual measures }\end{array}$ & Not clear & $\begin{array}{l}\text { Asthma assessed through } \\
\text { urinary LTE4 collected } \\
\text { every } 6 \text { days during the } \\
\text { study period }\end{array}$ & $\begin{array}{l}\text { Distribution of summed DAPs in this } \\
\text { study were significantly higher than } \\
\text { NHANES levels. Increase in uLTE4 } \\
\text { levels were associated with increased } \\
\text { exposures to DAPs, being significant } \\
\text { only for EDE levels, after adjustment: } \\
\quad 8.7(95 \% \text { CI: } 2.8,14.6) \text {. }\end{array}$ \\
\hline
\end{tabular}

Notes: $\mathrm{OP}=$ organophosphate pesticides; Th1 $=$ T-helper 1 ; Th2 $=$ T-helper 2; DAP = dialkyl phosphate metabolites; [] = concentrations; FEV $1=$ forced expiratory volume in first second;

$\mathrm{CI}=$ confidence interval; FVC = Forced vital capacity; $\mathrm{PM}_{2.5}=$ particulate matter $<2.5 \mu \mathrm{g}$; LTE4 = Leukotriene E4; uLTE4 = urinary Leukotriene E4; EDE = diethyl alkyl phosphate. 
Table 2. Studies on respiratory and allergic effects of organochlorine pesticides (OC) in children.

\begin{tabular}{|c|c|c|c|c|c|c|c|c|}
\hline $\begin{array}{l}\text { Author, Year } \\
\text { and Country }\end{array}$ & Study Sample & Study Design & $\begin{array}{l}\text { Pesticides } \\
\text { Addressed }\end{array}$ & $\begin{array}{l}\text { Exposure Pathway and } \\
\text { Activity }\end{array}$ & $\begin{array}{l}\text { Exposure Assessment } \\
\text { Method }\end{array}$ & Period of Exposure & $\begin{array}{l}\text { Health Effect and } \\
\text { Assessment Method }\end{array}$ & Results \\
\hline $\begin{array}{l}\text { Dallaire, F. et al. } \\
\text { 2004/Canada }\end{array}$ & $\begin{array}{l}199 \text { Inuit infants } \\
\text { up to } 12 \text { months }\end{array}$ & $\begin{array}{c}\text { Review of } \\
\text { medical charts }\end{array}$ & DDE & $\begin{array}{l}\text { Environmental exposure, } \\
\text { especially the consumption } \\
\text { of fish and marine } \\
\text { mammal fat }\end{array}$ & $\begin{array}{l}\text { Maternal plasma during } \\
\text { delivery and infant plasma at } \\
7 \text { months of age }\end{array}$ & Prenatal and at infancy & $\begin{array}{l}\text { Comparison of incidence } \\
\text { rates of upper and lower } \\
\text { respiratory tract infections } \\
\text { (URTIs and LRTIs, } \\
\text { respectively) in two } \\
\text { follow-ups } 6 \text { and } \\
12 \text { months) }\end{array}$ & $\begin{array}{l}\text { Compared to rates for infants in the } \\
\text { first quartile of DDE exposure (least } \\
\text { exposed), adjusted RR for infants in } \\
\text { higher quartiles ranged between } 1.15 \\
\text { and } 1.56 \text { for URTIs, and } 0.96 \text { and } 1.40 \\
\text { for LRTIs at the } 6 \text { months follow-up, } \\
\text { while it ranged from } 1.09 \text { to } 1.34 \text { for } \\
\text { URTIs, and from } 0.98 \text { to } 1.13 \text { for LRTI } \\
\text { at the } 12 \text { months follow-up, suggesting } \\
\text { a possible association between } \\
\text { prenatal exposure to OCs and acute } \\
\text { infections early in life. Despite most } \\
\text { RR were > } 1.0 \text {, only URTIs at the } 2^{\text {nd }} \\
\text { quartile were statistically significant a } \\
\text { both follow-up. }\end{array}$ \\
\hline $\begin{array}{l}\text { Gascon M., et al. } \\
\text { 2007/Spain }\end{array}$ & $\begin{array}{l}405 \text { children } \\
\text { aged up to } 14 y\end{array}$ & $\begin{array}{l}\text { Longitudinal } \\
\text { birth cohort }\end{array}$ & DDE & $\begin{array}{c}\text { Non-specific } \\
\text { environmental exposure }\end{array}$ & $\begin{array}{c}\text { DDE [] at cord blood samples, } \\
\text { and immune biomarkers at } \\
\text { age } 4 y\end{array}$ & Prenatal exposure to DDE & $\begin{array}{l}\text { Occurrence of wheeze, } \\
\text { chest infections and } \\
\text { asthma through } \\
\text { questionnaire-based } \\
\text { interviews at years } 1,2,3, \\
4,6.5,10 \text { and } 14 \mathrm{y}\end{array}$ & $\begin{array}{l}\text { Prenatal DDE exposure was associated } \\
\text { with wheeze at age } 4 \mathrm{y}(\mathrm{RR} \text { per double } \\
\text { of }[]=1.35 ; 95 \% \mathrm{CI}: 1.07 ; 1.71) \text {, but not } \\
\text { thereafter. Prenatal exposure was } \\
\text { associated with children's respiratory } \\
\text { outcomes at different ages, but no } \\
\text { associations were found between the } \\
\text { immune biomarkers and DDE. }\end{array}$ \\
\hline $\begin{array}{l}\text { Cupul-Uicab, } \\
\text { L.A. et al. } \\
\text { 2014/Mexico }\end{array}$ & $\begin{array}{l}747 \text { newborn } \\
\text { singleton boys }\end{array}$ & $\begin{array}{l}\text { Longitudinal } \\
\text { birth cohort }\end{array}$ & DDE and DDT & $\begin{array}{l}\text { Chiapas where DDT was } \\
\text { applied in crops until } 1991 \\
\text { and for malaria control } \\
\text { until } 1998\end{array}$ & $\begin{array}{l}\text { Maternal serum samples, and } \\
\text { home visits }\end{array}$ & $\begin{array}{l}\text { Prenatal exposure and } \\
\text { from } 12 \text { months to } 21 \\
\text { months }\end{array}$ & $\begin{array}{l}\text { Mothers report on doctor } \\
\text { diagnosis of pneumonia, } \\
\text { bronchitis or other illness } \\
\text { such as LRTI }\end{array}$ & $\begin{array}{l}\text { Higher prenatal exposure to p,p-DDE } \\
\text { and p,p-DDT were not associated with } \\
\text { higher risk of LRTI before or after } \\
\text { adjustment for confounders. }\end{array}$ \\
\hline $\begin{array}{l}\text { Meng, G. et al. } \\
\text { 2016/China }\end{array}$ & $\begin{array}{c}620 \text { asthmatic } \\
\text { children, and } \\
218 \\
\text { non-asthmatic } \\
\text { children aged } \\
3-6 y\end{array}$ & $\begin{array}{l}\text { Hospital-based } \\
\text { Case-Control }\end{array}$ & OC & $\begin{array}{l}\text { Environmental exposure, } \\
\text { mainly from agriculture } \\
\text { and residential use }\end{array}$ & Self-completed questionnaire & Not clear & $\begin{array}{l}\text { Physician-diagnosed } \\
\text { asthma by questionnaire } \\
\text { and spirometry, and } \\
\text { questionnaire to assess } \\
\text { allergy symptoms (rhinitis } \\
\text { and eczema) }\end{array}$ & $\begin{array}{l}\text { Asthmatic children presented } \\
\text { significantly higher levels of } 7 \text { OC } \\
\text { pesticides }(\alpha-H C H, H C B, \beta-H C H, \\
\gamma \text {-HCH, Heptachlor, } \mathrm{p}, \mathrm{p}^{\prime}-\mathrm{DDE} \text { and } \\
\text { o,p'-DDT) than non-asthmatic } \\
\text { children. }\end{array}$ \\
\hline
\end{tabular}

Notes: $\mathrm{OC}=$ organochlorine pesticides; DDE = dichlorodiphenyldichloroethylene; URTIs = upper respiratory tract infections; LRTIs = lower respiratory tract infections; RR = relative risk;

$\mathrm{CI}=$ confidence intervals; [] = concentrations; DDT = dichlorodiphenyltrichloroethane; p,p-DDE, and p,p-DDT and o, $\mathrm{p}^{\prime}$-DDT = metabolites of DDE and DDT, respectively; $\alpha$-HCH, $\beta$-HCH and $\gamma-\mathrm{HCH}=$ metabolites of hexachlorocyclohexanes; $\mathrm{HCB}=$ hexachlorobenzene. 
Table 3. Studies on respiratory and allergic effects of multiple pesticides, elemental sulfur, and fumigants in children.

\begin{tabular}{|c|c|c|c|c|c|c|c|c|}
\hline $\begin{array}{l}\text { Author, Year and } \\
\text { Country }\end{array}$ & Study Sample & Study Design & Pesticides Addressed & $\begin{array}{l}\text { Exposure Pathway and } \\
\text { Activity }\end{array}$ & Exposure Assessment Method & Period of Exposure & $\begin{array}{l}\text { Health Effect and Assessment } \\
\text { Method }\end{array}$ & Results \\
\hline $\begin{array}{l}\text { Salameh, PR. et al. } \\
\text { 2003/Lebanon }\end{array}$ & $\begin{array}{l}3291 \text { children aged } \\
\text { 5-16y }\end{array}$ & Cross-sectional & Multiple pesticides & $\begin{array}{l}\text { Environmental exposure } \\
\text { of children from a } \\
\text { randomly selected sample } \\
\text { of public schools }\end{array}$ & $\begin{array}{l}\text { Standardized questionnaire and } \\
\text { residential exposure score, } \\
\text { based on residential, } \\
\text { para-occupational and domestic } \\
\text { exposures }\end{array}$ & Not clear & $\begin{array}{l}\text { Respiratory symptoms assessed by } \\
\text { using the American Thoracic } \\
\text { Society (ATS) questionnaire }\end{array}$ & 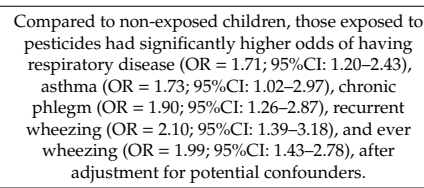 \\
\hline $\begin{array}{l}\text { Salam, MT. et al. } \\
\text { 2004/EUA }\end{array}$ & $\begin{array}{l}4000 \text { school-aged } \\
\text { children in } 12 \text { Southern } \\
\text { California }\end{array}$ & Case-control & $\begin{array}{l}\text { Multiple herbicides and } \\
\text { pesticides }\end{array}$ & $\begin{array}{l}\text { Children who had } \\
\text { early-life environmental } \\
\text { exposure to pesticides and } \\
\text { other contaminants }\end{array}$ & $\begin{array}{l}\text { Questionnaire and telephone } \\
\text { interviews with mothers to } \\
\text { collect additional exposure and } \\
\text { asthma history }\end{array}$ & $\begin{array}{l}\text { Prenatal and at first year of } \\
\text { life }\end{array}$ & $\begin{array}{l}\text { Physician-diagnosed asthma by } \\
\text { age 5, and controls were } \\
\text { asthma-free at study entry, } \\
\text { frequency-matched on age, sex, } \\
\text { and local of residence }\end{array}$ & 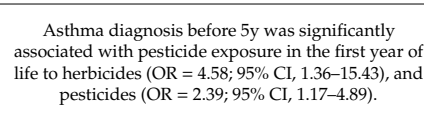 \\
\hline $\begin{array}{l}\text { Weselak, M. et al. } \\
\text { 2007/Canada }\end{array}$ & $\begin{array}{l}3405 \text { children aged } \\
0-12 y \text { or more, from } \\
\text { family farmers }\end{array}$ & Retrospective cohort & Multiple pesticides & Living on a family farm & $\begin{array}{l}\text { Questionnaires on pesticide use } \\
\text { and involvement in agricultural } \\
\text { activities }\end{array}$ & Prenatal & $\begin{array}{l}\text { Respiratory symptoms through a } \\
\text { questionnaire about health status }\end{array}$ & 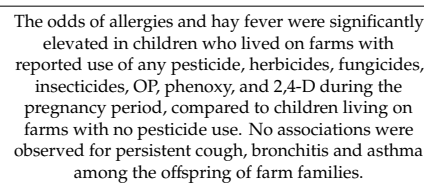 \\
\hline $\begin{array}{l}\text { Reardon AM. et al. } \\
\text { 2009/EUA }\end{array}$ & 652 children aged 5y & $\begin{array}{l}\text { Prospective birth } \\
\text { cohort study }\end{array}$ & $\begin{array}{l}\text { OP (chlorpyrifos and } \\
\text { diazinon), and } \\
\text { pyrethroids } \\
\text { (cis-permethrin and } \\
\text { trans-permethrin) }\end{array}$ & $\begin{array}{c}\text { Elementary school } \\
\text { children in California } \\
\text { having a mother working } \\
\text { in agriculture }\end{array}$ & $\begin{array}{l}\text { Retrospective questionnaire, } \\
\text { and measurement of prenatal } \\
\text { levels of pesticide }\end{array}$ & $\begin{array}{l}\text { Prenatal and first year of } \\
\text { life }\end{array}$ & $\begin{array}{l}\text { Questionnaire about wheeze and } \\
\text { analysis of IgE production (5y); } \\
\text { increased levels of TH } 2 \text { cytokines } \\
\text { in children (2y) }\end{array}$ & $\begin{array}{l}\text { Prenatal exposures to pesticides may influence the } \\
\text { risk of early cough, wheeze, and IgE production. } \\
\text { Individual pesticides may differ in regard to risk. }\end{array}$ \\
\hline $\begin{array}{l}\text { Tagiyeva, G. et al. } \\
\text { 2010/England }\end{array}$ & $\begin{array}{l}13,971 \text { children aged } \\
\text { up to } 102 \text { months }\end{array}$ & $\begin{array}{l}\text { Birth cohort-Avon } \\
\text { Longitudinal Study of } \\
\text { Parents and Children } \\
\text { (ALSPAC) }\end{array}$ & Biocides and fungicides & $\begin{array}{l}\text { Parental occupational } \\
\text { exposure to pesticides, } \\
\text { along with other } \\
\text { contaminants }\end{array}$ & $\begin{array}{l}\text { Questionnaire and clinic } \\
\text { evaluations }\end{array}$ & Up to 102 months & Questionnaire, clinical assessments & $\begin{array}{l}\text { Maternal postnatal occupational exposure to } \\
\text { biocideffungicide increased the likelihood of } \\
\text { childhood wheeze (OR }=1.22 ; 95 \% \text { cli: } 1.02-2.05) \text {. }\end{array}$ \\
\hline $\begin{array}{l}\text { Perla, ME. et al. } \\
\text { 2014/USA }\end{array}$ & $\begin{array}{l}\text { 10,077 children aged } \\
\text { from 6y to } 16 \mathrm{y}\end{array}$ & $\begin{array}{c}\text { Cross-sectional } \\
\text { population-based } \\
\text { (NHANES) }\end{array}$ & $\begin{array}{l}\text { Survey questionnaires } \\
\text { and exposure } \\
\text { biomarkers for } \\
\text { (DAP) and DDT }\end{array}$ & Environmental exposures & Blood and urine tests & Up to 16 years old & $\begin{array}{l}\text { Questionnaire, blood and urine } \\
\text { tests }\end{array}$ & 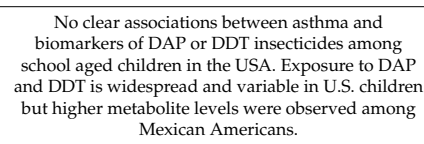 \\
\hline $\begin{array}{l}\text { Runkle, ,J et al. } \\
\text { 2014/USA }\end{array}$ & $\begin{array}{l}\text { Snowball sample with } \\
170 \text { farmworker } \\
\text { mothers (mostly from } \\
\text { Mexico, but also } \\
\text { indigenous from } \\
\text { Central America and } \\
\text { others) }\end{array}$ & $\begin{array}{l}\text { Cross-sectional survey } \\
\text { with participatory } \\
\text { approach(CBPR) }\end{array}$ & Multiple pesticides & $\begin{array}{l}\text { Mother's involvement in } \\
\text { agricilture at nurseries }(\mathrm{n} \\
=62) \text { and ferneries }(\mathrm{n}= \\
108) \text { pesticide handling } \\
\text { activities, father's work as } \\
\text { a farmer }\end{array}$ & $\begin{array}{l}\text { Interviews about current and } \\
\text { past work conditions (e.g., } \\
\text { duration of work in agriculture } \\
\text { while pregnant, father's work in } \\
\text { agriculture) }\end{array}$ & $\begin{array}{l}\text { Prenatal until 1y }(\sim 52 \% \\
\text { worked the entire } \\
\text { pregnancy period and } \\
\sim 48 \% \text { worked partially })\end{array}$ & $\begin{array}{l}\text { Interview about outcomes during } \\
\text { last pregnancy infant's health for } \\
\text { the first year of life and } \\
\text { doctor-diagnosed respiratory and } \\
\text { breathing problems }\end{array}$ & $\begin{array}{l}\text { Most self-reported child health problems were } \\
\text { respiritort-related ( } 766^{2} \% \text {. Significiantly more } \\
\text { mothers working in ferneries reported child } \\
\text { diagnosis of any health problem and were 2.27 times } \\
\text { more likely to report child diagnosis of respiratory } \\
\text { condition, compared to nursery workers. }\end{array}$ \\
\hline $\begin{array}{l}\text { Raanan, R. et al. } \\
\text { 2017/USA }\end{array}$ & $\begin{array}{l}347 \text { children aged } 7 y \\
\text { living in an } \\
\text { agricultural } \\
\text { community }\end{array}$ & $\begin{array}{c}\text { Longitudinal birth } \\
\text { cohort (CHAMACOS) }\end{array}$ & Elemental sulfur & $\begin{array}{l}\text { Residential proximity to } \\
\text { agriculturara areas with } \\
\text { elemental sulfur } \\
\text { applications }\end{array}$ & $\begin{array}{l}\text { Sulfur application within } 0.5,1, \\
\text { and 3km of residences during } \\
\text { the week, month, and } \\
12 \text { months prior to pulmonary } \\
\text { evaluation using California's } \\
\text { Pesticide Use Report (PUR) data }\end{array}$ & $\begin{array}{l}\text { Short-term exposure (week, } \\
\text { month and a year) before } \\
\text { the pulmonary assessment }\end{array}$ & $\begin{array}{l}\text { Respiratory symptoms through } \\
\text { questionnaires (ISAAC) with } \\
\text { mothers, and spirometry with } \\
\text { children at 7y }\end{array}$ &  \\
\hline
\end{tabular}


Table 3. Cont.

\begin{tabular}{|c|c|c|c|c|c|c|c|c|}
\hline $\begin{array}{l}\text { Author, Year and } \\
\text { Country }\end{array}$ & Study Sample & Study Design & Pesticides Addressed & $\begin{array}{l}\text { Exposure Pathway and } \\
\text { Activity }\end{array}$ & Exposure Assessment Method & Period of Exposure & $\begin{array}{l}\text { Health Effect and Assessment } \\
\text { Method }\end{array}$ & Results \\
\hline $\begin{array}{l}\text { Dayasiri, KC. et al. } \\
\text { 2017/Sri Lanka }\end{array}$ & $\begin{array}{l}155 \text { children aged } 9 \\
\text { months to 12y with } \\
\text { pesticide poisoning }\end{array}$ & $\begin{array}{l}\text { Retrospective and } \\
\text { prospective } \\
\text { hospital-based } \\
\text { multisite study } \\
\text { (admissions from 2007 } \\
\text { to 2014) }\end{array}$ & $\begin{array}{l}\text { Most frequent: OP } \\
(41 \%), \text {, CM }(23 \%) \text { and } \\
\text { herbicides }(12 \%)\end{array}$ & $\begin{array}{l}51.3 \% \text { were exposed at } \\
\text { cultivation sites, } 18.9 \% \text { at } \\
\text { home gardens, and } 16.2 \% \\
\text { at home kitchens }\end{array}$ & $\begin{array}{l}\text { Questionnaire-based interviews } \\
\text { in hospital admission }\end{array}$ & Not clear & $\begin{array}{l}\text { Prevalence of respiratory } \\
\text { symptoms among poisoned } \\
\text { children, along with other } \\
\text { symptoms }\end{array}$ & 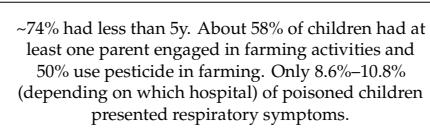 \\
\hline $\begin{array}{l}\text { Kudagammana, ST.; } \\
\text { Mohotti, K. 2018/Sri } \\
\text { Lanka }\end{array}$ & $\begin{array}{c}182 \text { preschool children } \\
\text { aged 1-5y from an } \\
\text { organic area }(n=81) \\
\text { and conventional area } \\
(n=101) \\
\end{array}$ & Cross-sectional & Multiple pesticides & $\begin{array}{l}\text { Children living close to } \\
\text { tea plantations } \\
\text { (conventional vs. organic) }\end{array}$ & $\begin{array}{l}\text { Children from a conventional } \\
\text { tea plantation were compared to } \\
\text { children from an organic tea } \\
\text { cultivation area }\end{array}$ & Not clear & $\begin{array}{c}\text { Prevalence of allergic diseases } \\
\text { througha questionnair-based } \\
\text { interview using the modified } \\
\text { International study of Asthma and } \\
\text { allergies (ISAAC) }\end{array}$ & $\begin{array}{l}\text { Wheezing was noted in } 41.2 \% \text { of children from the } \\
\text { organic estate and } 59.8 \% \text { from the convertional estate. } \\
\text { The respective perentages for allergic rhinitis were } \\
\text { as } 37.7 \% \text { and } 82.5 \% \text { while for eccerma they were 17.5\% } \\
\text { and } 20.3 \% \text {. }\end{array}$ \\
\hline $\begin{array}{l}\text { Gunier, RB. et al. } \\
\text { 2018/USA }\end{array}$ & $\begin{array}{l}294 \text { children living in } \\
\text { an agricultural area }\end{array}$ & $\begin{array}{c}\text { Longitudinal birth } \\
\text { cohort CHAMACOS }\end{array}$ & $\begin{array}{l}\text { Fumigants (methyl } \\
\text { bromide, chloropicrin, } \\
\text { metam sodium and } \\
\text { 1,3-dichloropropene) }\end{array}$ & $\begin{array}{l}\text { Residential proximity to } \\
\text { agricultural areasu using } \\
\text { fumigants }\end{array}$ & $\begin{array}{l}\text { Fumigant use within } 3,5 \text { and } 8 \\
\mathrm{~km} \text { of residences during } \\
\text { pregnancy and from birth to age } \\
7 \text { using PUR data }\end{array}$ & $\begin{array}{l}\text { Prenatal and from } \\
\text { cumulativive exposure from } \\
\text { birth to } 7 y\end{array}$ & $\begin{array}{l}\text { Respiratory symptoms (ISAAC) } \\
\text { and asthma medication use } \\
\text { through questionnaires with } \\
\text { mothers, and spirometry with } \\
\text { children at } 7 y \\
\end{array}$ & $\begin{array}{l}\text { No significant associations were observed between } \\
\text { residential proximity to fumigants use and } \\
\text { respiratory symptoms, use of asthma medication, } \\
\text { and lung function measurements. }\end{array}$ \\
\hline $\begin{array}{l}\text { Raherison, C. et al. } \\
\text { 20191/France }\end{array}$ & $\begin{array}{l}281 \text { children aged } \\
\text { 3-10y from 4 rural } \\
\text { schools of a French } \\
\text { vineyard region }\end{array}$ & $\begin{array}{l}\text { Cross-sectional with } \\
\text { two phases: during } \\
\text { winter with no } \\
\text { pesticide exposure, } \\
\text { and summer, when } \\
\text { pesticides are } \\
\text { regularly applied }\end{array}$ & $\begin{array}{l}\text { Multiple pesticides } \\
\text { (insecticides, } \\
\text { herbicides and } \\
\text { fungicides) in outdoor } \\
\text { air around schools, and } \\
\text { phthalimides and } \\
\text { dithiocarbamate } \\
\text { fungicides in urine } \\
\text { (ETU) }\end{array}$ & $\begin{array}{l}\text { Proximity of schools from } \\
\text { the } \\
\text { edge of vineyards }\end{array}$ & $\begin{array}{l}\text { Mobile stations located close to } \\
\text { the schools for air monitoring, } \\
\text { and urine measurements in a } \\
\text { subset }(n=96) \text { of studied } \\
\text { children }\end{array}$ & Not clear & 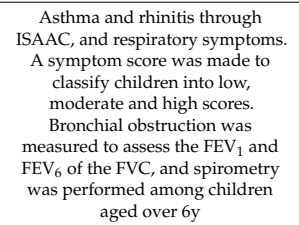 & 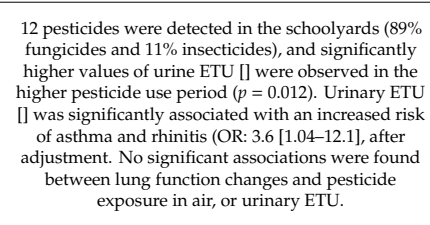 \\
\hline
\end{tabular}

Notes: $\mathrm{OR}=$ odds ratio; $\mathrm{CI}$ = confidence intervals; $\mathrm{OP}$ = organophosphate pesticides; 2,4-D = 2,4-Dichlorophenoxyacetic acid; IgE = Immunoglobulin E; TH-2 = T helper cells type 2; DAP

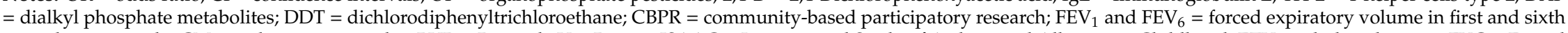
second, respectively; CM = carbamate pesticides; PUR = Pesticide Use Report; ISAAC = International Study of Asthma and Allergies in Childhood; ETU = ethylenethiourea; FVC = Forced vital capacity; [] = concentrations. 
Although OC has been banned in almost all countries, due to its long half-life it is still found in many human and environmental matrices. OC has been replaced by pesticides considered less persistent, but which were later shown to also be very toxic, such as OP, CM, and pyrethroids, among others [23]. Recent epidemiological studies have shown increasing evidence of the respiratory effects of pesticide exposure, raising concern for this public health issue.

To date, only 21 epidemiological studies were indexed in the searched databases about the effects of agricultural pesticide exposure on childhood respiratory and allergic health. Of the 21 articles included in this review, some belonged to the same research project/program, resulting in 16 independent studies. Of these, 8 were cohort studies (7 prospective and 1 retrospective), 3 cross-sectional, 2 case-control, 2 hospital-based analyses of admissions and medical charts, and 1 retrospective survey. Five studies were about the CHAMACOS cohort study from University of California, Berkeley.

The first study was published in 2003 and since then, there was a discrete upward tendency, with no publications during several years such as in 2005, 2008, and between 2011 and 2013 (Figure 2).

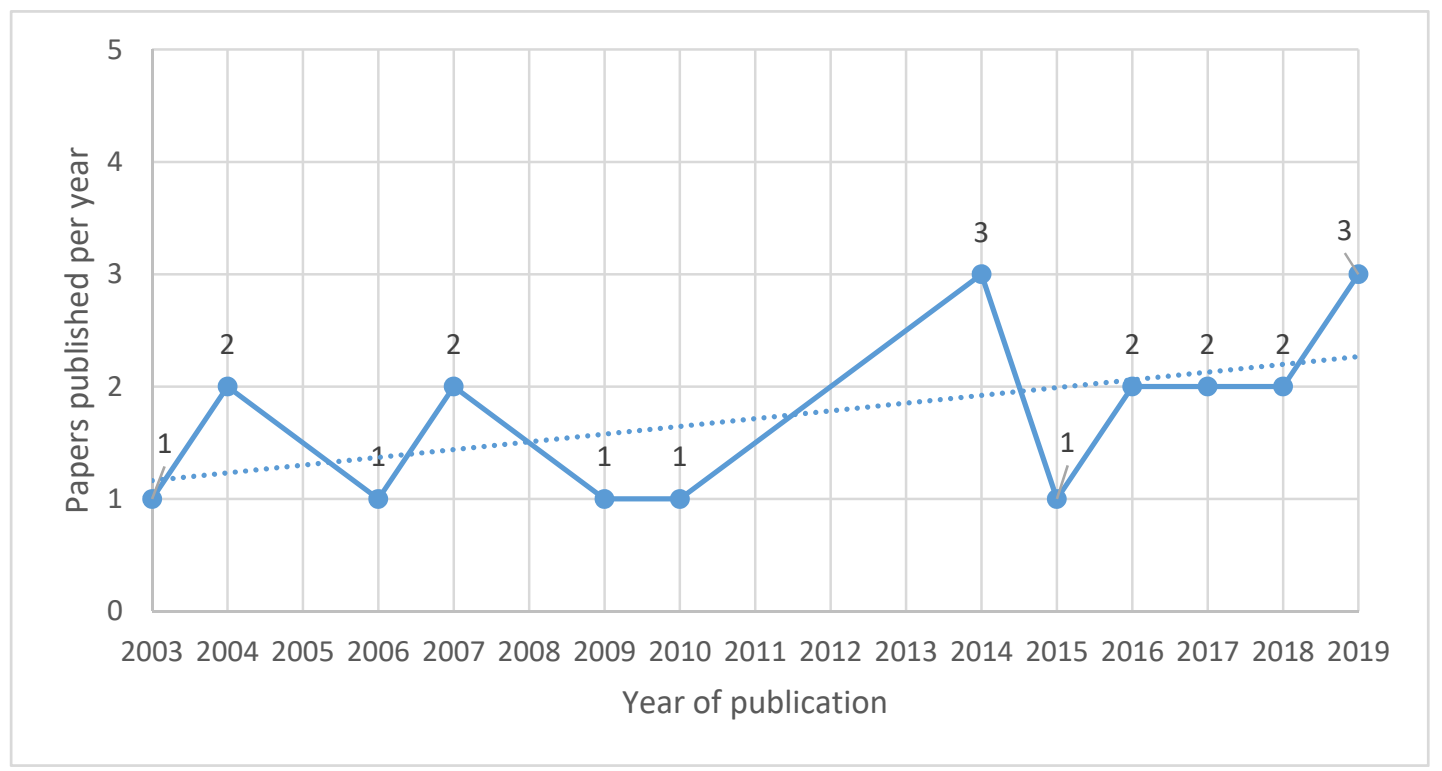

Figure 2. Number of papers published per year focused on children's respiratory and allergic effects of pesticide exposure $(n=21)$.

All studies were located in three continents (North America, Asia and Europe), while Latin America and Africa had no studies, despite their intensive use of pesticides. A study conducted in Niger compared the respiratory effects on children from exposure to agricultural and pasture areas using questionnaires, but the results indicated that no farmer was using pesticides for agricultural purposes, only at home. Although an association between residential use of pesticides and cough without fever has been indicated among children, the article was not included in this review, which focuses solely on the agricultural use of pesticides [24]. As shown in Table 4, the majority of studies were conducted in the North American region, and more than half were from the United States.

Table 4. Regional distribution of the articles considered in the present study.

\begin{tabular}{cccc}
\hline Region & Number of Articles & $\%$ & Countries $(\boldsymbol{n}, \mathbf{\%})$ \\
\hline Asia & 4 & 19.0 & $\begin{array}{c}\text { Sri Lanka }(n=2,9.5 \%) ; \text { Lebanon and China }(n=1 \text { each, } 4.8 \%) \\
\text { Furope }\end{array}$ \\
$\begin{array}{c}\text { Northce, England, and Spain }(n=1 \text { each, } 4.8 \%) \\
\text { America }\end{array}$ & 14 & 14.3 & $\begin{array}{c}\text { United States }(n=11,52.4 \%) ; \text { Canada }(n=2,9.5 \%) ; \text { Mexico } \\
(n=1,4.8 \%)\end{array}$ \\
\hline Total & 21 & 66.7 & 10 countries in total \\
\hline
\end{tabular}

Note: There were no studies conducted in Africa nor in South America. 
Pesticide exposure may disproportionally affect lower and middle-income countries, where regulation, surveillance and farmer's technical support are weaker and less rigorous $[25,26]$. In these countries, frequent exposure to multiple highly toxic chemicals without proper personal protection is common, and has been associated with respiratory health impacts in adults exposed occupationally [2,7,27-29], possibly overloading the health systems. It is estimated that $99 \%$ of the poisoning cases of pesticide exposure occur in low and middle-income countries [30], but contrastingly most studies included in this review were located in high-income countries. Although some children's health effects of pesticide exposure have been studied recently in lower income countries [31-33], respiratory outcomes are still understudied.

The study sample size and age of subjects varied widely among the 21 studies included in this review. The study with the least number of participants was a U.S. cohort that followed 16 children aged 6 to $16 y$ ( 2 articles published), and the study that included the most participants followed a British birth cohort (ALSPAC) of 13,971 children aged up to 8.5y, and a U.S. cross-sectional population based study (NHANES) of 10,077 children aged 6 to 16y. Of all the studies, 33\% $(n=7)$ reported childhood respiratory effects at specific ages (being one, two, and four studies respectively with children aged 1 , 5 , and 7 years), while $66 \%(n=14)$ presented results of children of a wide age range, varying from newborns to 16 years old. These great differences in the studies' sample sizes and subjects' ages hamper the comparison of the results by specific age ranges.

Children's exposure to pesticides often begins before birth through the mother's and father's occupational exposure to pesticides, and tends to continue thereafter. A study of 260 farmworker mothers observed that all of them worked during pregnancy either entirely, or partially and have stopped working at week $22.8 \pm 7.9$ (mean, sd). They also reported that $\sim 52 \%$ of the fathers worked in agriculture during pregnancy [34]. Twelve studies assessed respiratory effects considering prenatal exposure to pesticides, with only two of them focusing exclusively on prenatal exposure. One of them found that prenatal exposure to DDE (concentration at cord blood samples) was associated with wheezing at age $4 y$, but not thereafter, and with other respiratory outcomes at different ages [35]. Another study, which investigated children living on farms with pesticide use compared to children living on farms with no pesticide use, found that prenatal exposure to pesticides was associated with significantly higher odds of developing allergies and hay fever, but was not associated with coughs, bronchitis and asthma [36].

Children are exposed to pesticides through multiple pathways, which can include: having a mother exposed to pesticides while pregnant, living or studying near areas with pesticide use, attending agricultural areas, having parents working in agriculture, having residential exposure through take-home exposure, and eating and drinking contaminated food and water, among others [10,37]. A hospital-based multisite study in Sri Lanka observed that most children poisoned with pesticides had at least one parent engaged in farming activities $(\sim 58 \%)$, and were exposed at cultivation sites $(\sim 51 \%)[38]$.

Five out of the 21 studies included in this review used the parent's occupational exposure to pesticides as a proxy for exposure. Of these, one study found that prenatal and childhood OP exposure (assessed by DAP metabolites) was non-significantly associated with respiratory symptoms at 5y and $7 y$ [19], but was associated with significant decreases in lung function at age 7 in another study [20]. Prenatal exposure to pesticides (OP and pyrethroids) was shown to increase the risk of early cough, wheeze, and IgE production [22], and maternal postnatal occupational exposure to biocides/fungicides increased the likelihood of childhood wheeze [39]. Moreover, mothers working in ferneries were 2.7 times more likely to report a child's diagnosis of a respiratory condition, compared to nursery farm workers [34]. While nursery farm workers are less exposed due to the lower height of the exposure, those working at ferneries apply pesticides at the same level as their breathing.

Four studies assessed the children's respiratory effects from the residential proximity to pesticide application areas. Two studies found that asthma (observed through increased uLTE4 levels) was associated with OP exposure among children of farmers who live close to cultivation sites, with this 
association being significant only for diethyl alkyl phosphate (EDE) [40], even when PM 2.5 was considered as a joint exposure [41].

Childhood respiratory symptoms, asthma prevalence and pulmonary function changes were associated with elemental sulfur applications within 0.5 and $1 \mathrm{~km}$ radii of the residence [42], but non-significant associations were observed for residential proximity to fumigants used in the same cohort [43]. Furthermore, one study explored the children's school proximity to the cultivation areas with pesticide use and respiratory effects, and found that urinary CM metabolite levels (by ETU concentration) were significantly associated with an increased risk of asthma and rhinitis [44].

Three other studies considered the very fact of children living in rural areas as a proxy for exposure. Associations between an increased prevalence of asthma and wheeze, and elevated Th2 levels among children exposed to OP at early ages in the U.S. were observed [45]; there were also significantly higher odds of allergies and hay fever in Canadian children who lived on farms with pesticide use during pregnancy, compared to children living on farms with no pesticide use [36]; and a higher prevalence of respiratory symptoms such as wheezing, allergic rhinitis, and eczema were found among rural children from conventional tea plantations compared to children from an organic tea cultivation in Sri Lanka [46].

Ten out of the 21 studies $(47.7 \%)$ assessed the health effects of combined exposure to more than one pesticide, including OP, carbamates (CM), pyrethroids, herbicides, fungicides and biocides. Moreover, five studies (23.8\%) addressed the specific effects of OP, four $(19.0 \%)$ investigated exposure to organochlorines (OC), mainly DDT and its main metabolite DDE, while the two remaining studies focused on exposure to elemental sulfur and fumigants (one each).

Exposure to OP was significantly associated with asthma and wheeze in children at early ages [45], decreases in lung function at 7 years old [20], and increased chances of developing asthma [40,41]. The combined exposure including OP (with pyrethroids) was related to higher risk of early cough, wheeze, and IgE as a biomarker for allergies [22], while no associations were found between asthma and biomarkers of DAP or DDT insecticides among 10,077 school aged children in a population-based study in the U.S. [21]. Contrastingly, prenatal and childhood exposure to OP through DAP metabolites were not associated with respiratory symptoms at $5 y$ and $7 y$ [19].

Prenatal exposure to OC was associated with respiratory tract infections early in life among 199 Inuit infants, a population that is mostly exposed through fish and mammal fat consumption [47]. In another study, prenatal exposure to OC was associated with wheeze at age $4 y$, but not thereafter, and other respiratory outcomes at different ages up to 14 years old [35]. In a hospital-based case control study with 620 Chinese children aged 3 to 6 years, asthmatic children presented significantly higher levels than non-asthmatic children of seven OC chemicals $(\alpha-\mathrm{HCH}, \mathrm{HCB}, \beta-\mathrm{HCH}, \gamma-\mathrm{HCH}, \mathrm{Heptachlor}$, $\mathrm{p}, \mathrm{p}^{\prime}$-DDE and o,p'-DDT) [48]. A study of 747 boys aged 12 to 21 months in Mexico investigated the effects of pesticides applied for malaria control in maternal serum samples, and found no associations with lower respiratory tract infections such as pneumonia and bronchiolitis [49].

Eight studies addressed the childhood respiratory effects of multiple pesticides combined through questionnaires and interviews, and observed significantly higher odds of developing asthma, wheezing, and chronic phlegm [15], and also wheezing, allergic rhinitis and eczema [46], when compared with non-exposed children. Maternal postnatal exposure to biocides and fungicides at work was associated with an increased risk of childhood wheeze [39]. Asthma diagnosis before 5 years old was also associated with exposure in the first year of life to herbicides and other pesticides [16].

CM exposure (measured through urinary ETU) in a school located in a vineyard area with high pesticide use was significantly associated with an increased risk of asthma and rhinitis, but not of lung function changes [44].

Two studies had no clear associations between exposure to pesticides and health effects, with one of them being a comparison between ferneries and nursery farm workers [34], and the other a multisite hospital-based study assessing the prevalence of respiratory symptoms among poisoned children [38]. The former presents differences on regarding the type of activities regarding plants with 
different morphologies. While nursery farm workers are less exposed due to the lower height of the exposure, those working at ferneries apply pesticides at the same level of their breathing. The later reported respiratory symptoms in about $8.6 \%-10.8 \%$ of poisoned children, and most had at least one parent engaged in farming activities [38].

Finally, 15 out of the 19 remaining studies (79\%) included in this review found positive associations between pesticide exposure and childhood respiratory and allergic effects, mainly asthma [15,16,40-42,45,48], wheezing [15,22,39,45,46], allergic rhinitis and eczema [46], coughing and allergies [22], respiratory acute infections [47], chronic phlegm [15], and lung function impairments [20].

Prenatal exposure to DDE was associated with children's respiratory outcomes at different ages, and with wheeze at age 4, but not thereafter [35]. Significantly higher odds of allergies and hay fever were observed among children who lived on farms with pesticide use during pregnancy, compared to children living on farms with no pesticide use, but no relation was observed for cough, bronchitis and asthma [36]. Urinary ETU levels (as biomarkers for CM) were significantly associated with an increased risk of asthma and rhinitis, after adjustment, but no significant associations were found between lung function changes [44].

Contrastingly, four studies out of the 19 remaining studies (21\%) found no associations between exposure to pesticides and respiratory or allergic health effects. Prenatal and childhood exposure to OP (assessed through urinary DAP) were non-significantly associated with respiratory symptoms at ages 5 and 7 years old [19]. Higher prenatal exposure to OC ( $p, p$-DDE and $p, p$-DDT in maternal serum) was not associated with a higher risk of lower respiratory tract infections [49].

A population-based study in U.S. did not observe clear associations between asthma and OP and OC exposure (which was measured using biomarkers of DAP or DDT insecticides) among school-aged children [21]. No significant associations were observed between residential proximity to fumigant use during pregnancy and from birth to age 7 (assessed through the pesticide use registration in California) and respiratory symptoms, use of asthma medication, and lung function measurements [43].

The correlation of respiratory and allergic effects between the studies included in this review was compromised by the considerable variability in the studies' characteristics (or lack of information), which represents a risk of bias for comparison across studies. For instance, the studies' differences were related to a) study and participants: study design, health outcomes, and health assessment methods, number and characteristics of participants (e.g., age range and sex), and follow-up period; and b) exposure: types of pesticides, quantity, frequency and methods of utilization, exposure pathway, and assessment method. Despite these limitations, this review presents relevant findings to help understand how children are exposed to agricultural pesticides and the respiratory and allergic effects of such exposure.

\section{Conclusions}

This comprehensive review gathered published evidence on the respiratory and allergic effects of agricultural pesticide exposure in children. It shows that children have been exposed to pesticides through multiple sources and pathways from the prenatal period throughout early development, and this may have several respiratory effects such as asthma, wheezing, cough, allergies, and pulmonary function impairment. Although environmental exposure to pesticides has been associated with an increased risk of respiratory outcomes among children, the causal relationship is still under debate, and more scientific evidence must be produced.

Children from low- and middle-income countries are probably the most affected due to excessive use of highly toxic pesticides, lack of occupational training and protective measures, and high environmental and take-home exposure, among other factors [10,25]. However, most studies are still being conducted in high-income countries. Therefore, this review highlights the necessity of more studies in low- and middle-income countries, especially those with larger food production, which may employ more conventional methods of pesticide use and have large child populations in rural areas and helping in agricultural work. Furthermore, novel methods have been used to explore the health 
effects of environmental contaminants, such as metabolomics, which may be valuable to advance the current knowledge of the mechanisms of respiratory and allergic effects.

In this study, the comparison of the effects of exposure to pesticides was hampered by study differences, such as the types of pesticide investigated, exposure pathway and assessment method, and age range, among others. The development and validation of international research protocols, adapted to local specificities, should help to develop comparable studies in different settings, facilitating a better understanding of the complexities of pesticide exposure and resulting health effects.

Despite its limitations, this review provides important epidemiological evidence that reinforces the relevance of strengthening public policies to protect children's health. We recommend additional research to fully characterize childhood exposure pathways to pesticides and the links with respiratory health outcomes. Moreover, efforts should be made globally in order to develop more comprehensive risk mitigation strategies and behavioral interventions based on the current information, seeking to minimize children's exposure to agricultural pesticides and respiratory health effects.

Author Contributions: Conceptualization, R.J.B. and H.R.; methodology, R.J.B.; formal analysis, R.J.B., A.F.D. and H.R.; data curation, R.J.B., A.F.D. and H.R.; writing-original draft preparation, R.J.B.; writing-review and editing, R.J.B., A.F.D. and H.R.; supervision, H.R.; project administration, R.J.B. All authors have read and agreed to the published version of the manuscript.

Funding: This research received no external funding, although RJB is funded by the Coordination for the Improvement of Higher Education Personnel (CAPES), and HR is funded by the Brazilian National Council for Scientific and Technological Development (CNPq). This article's APC was also funded by CAPES.

Conflicts of Interest: The authors declare no conflict of interest.

\section{References}

1. Fareed, M.; Pathak, M.K.; Bihari, V.; Kamal, R.; Srivastava, A.K.; Kesavachandran, C.N. Adverse respiratory health and hematological alterations among agricultural workers occupationally exposed to organophosphate pesticides: A cross-sectional study in North India. PLoS ONE 2013, 8, e69755. [CrossRef]

2. Chakraborty, S.; Mukherjee, S.; Roychoudhury, S.; Siddique, S.; Lahiri, T.; Ray, M.R. Chronic Exposures to Cholinesterase-inhibiting Pesticides Adversely Affect Respiratory Health of Agricultural Workers in India. J. Occup. Heal. 2009, 51, 488-497. [CrossRef] [PubMed]

3. Baldi, I.; Robert, C.; Piantoni, F.; Tual, S.; Bouvier, G.; Lebailly, P.; Raherison, C. Agricultural exposure and asthma risk in the AGRICAN French cohort. Int. J. Hyg. Environ. Health 2014, 217, 435-442. [CrossRef] [PubMed]

4. Hoppin, J.A.; Umbach, D.M.; London, S.J.; Henneberger, P.K.; Kullman, G.J.; Coble, J.; Alavanja, M.C.R.; Beane Freeman, L.E.; Sandler, D.P. Pesticide use and adult-onset asthma among male farmers in the Agricultural Health Study. Eur. Respir. J. 2009, 34, 1296-1303. [CrossRef]

5. Shama, F.A.; Skogstad, M.; Nijem, K.; Bjertness, E.; Kristensen, P. Cross-shift changes in lung function among palestinian farmers during high- and low-exposure periods to pesticides: A longitudinal study. Arch. Environ. Occup. Heal. 2015, 70, 218-224. [CrossRef]

6. De Jong, K.; Boezen, H.M.; Kromhout, H.; Vermeulen, R.; Postma, D.S.; Vonk, J.M. Association of occupational pesticide exposure with accelerated longitudinal decline in lung function. Am. J. Epidemiol. 2014, 179, 1323-1330. [CrossRef]

7. Buralli, R.J.; Ribeiro, H.; Mauad, T.; Amato-Lourenço, L.F.; Salge, J.M.; Diaz-Quijano, F.A.; Leão, R.S.; Marques, R.C.; Silva, D.S.; Guimarães, J.R.D. Respiratory condition of family farmers exposed to pesticides in the state of Rio de Janeiro, Brazil. Int. J. Environ. Res. Public Health 2018, 15, 1203. [CrossRef]

8. Ye, M.; Beach, J.; Martin, J.W.; Senthilselvan, A. Occupational pesticide exposures and respiratory health. Int. J. Environ. Res. Public Health 2013, 10, 6442-6471. [CrossRef]

9. Mamane, A.; Raherison, C.; Tessier, J.F.; Baldi, I.; Bouvier, G. Environmental exposure to pesticides and respiratory health. Eur. Respir. Rev. 2015, 24, 462-473. [CrossRef]

10. Hyland, C.; Laribi, O. Review of take-home pesticide exposure pathway in children living in agricultural areas. Environ. Res. 2017, 156, 559-570. [CrossRef] 
11. Bradman, A.; Castorina, R.; Barr, D.B.; Chevrier, J.; Harnly, M.E.; Eisen, E.A.; McKone, T.E.; Harley, K.; Holland, N.; Eskenazi, B. Determinants of organophosphorus pesticide urinary metabolite levels in young children living in an agricultural community. Int. J. Environ. Res. Public Health 2011, 8, 1061-1083. [CrossRef] [PubMed]

12. Lu, C.; Toepel, K.; Irish, R.; Fenske, R.A.; Barr, D.B.; Bravo, R. Organic diets significantly lower children's dietary exposure to organophosphorus pesticides. Environ. Health Perspect. 2006, 114, 260-263. [CrossRef] [PubMed]

13. Marks, A.R.; Harley, K.; Bradman, A.; Kogut, K.; Barr, D.B.; Johnson, C.; Calderon, N.; Eskenazi, B. Organophosphate pesticide exposure and attention in young Mexican-American children: The CHAMACOS study. Environ. Health Perspect. 2010, 118, 1768-1774. [CrossRef] [PubMed]

14. Roberts, J.R.; Karr, C.J. Pesticide exposure in children. Pediatrics 2012, 130, 11. [CrossRef]

15. Salameh, P.R.; Baldi, I.; Brochard, P.; Raherison, C.; Saleh, B.A.; Salamon, R. Respiratory symptoms in children and exposure to pesticides. Eur. Respir. J. 2003, 22, 507-512. [CrossRef]

16. Salam, M.T.; Li, Y.F.; Langholz, B.; Gilliland, F.D. Early-life environmental risk factors for asthma: Findings from the children's health study. Environ. Health Perspect. 2004, 112, 760-765. [CrossRef]

17. Xu, X.; Nembhard, W.N.; Kan, H.; Becker, A.; Talbott, E.O. Residential pesticide use is associated with children's respiratory symptoms. J. Occup. Environ. Med. 2012, 54, 1281-1287. [CrossRef]

18. Bukalasa, J.S.; Brunekreef, B.; Brouwer, M.; Koppelman, G.H.; Wijga, A.H.; Huss, A.; Gehring, U. Associations of residential exposure to agricultural pesticides with asthma prevalence in adolescence: The PIAMA birth cohort. Environ. Int. 2018, 121, 435-442. [CrossRef]

19. Raanan, R.; Harley, K.G.; Balmes, J.R.; Bradman, A.; Lipsett, M.; Eskenazi, B. Early-life exposure to organophosphate pesticides and pediatric respiratory symptoms in the CHAMACOS cohort. Environ. Health Perspect. 2015, 123, 179-185. [CrossRef]

20. Raanan, R.; Balmes, J.R.; Harley, K.G.; Gunier, R.B.; Magzamen, S.; Bradman, A.; Eskenazi, B. Decreased lung function in 7-year-old children with early-life organophosphate exposure. Thorax 2016, 71, 148-153. [CrossRef]

21. Perla, M.E.; Rue, T.; Cheadle, A.; Krieger, J.; Karr, C.J. Biomarkers of Insecticide Exposure and Asthma in Children: A National Health and Nutrition Examination Survey (NHANES) 1999-2008 Analysis. Arch. Environ. Occup. Heal. 2015, 70, 309-322. [CrossRef] [PubMed]

22. Reardon, A.M.; Perzanowski, M.S.; Whyatt, R.M.; Chew, G.L.; Perera, F.P.; Miller, R.L. Associations between prenatal pesticide exposure and cough, wheeze, and IgE in early childhood. J. Allergy Clin. Immunol. 2009, 124, 852-854. [CrossRef] [PubMed]

23. Carvalho, F.P. Pesticides, environment, and food safety. Food Energy Secur. 2017, 6, 48-60. [CrossRef]

24. Mamane, A.; Tessier, J.-F.; Bouvier, G.; Salamon, R.; Lebailly, P.; Raherison, C.; Baldi, I.; Baldi, I. Increase in the Risk of Respiratory Disorders in Adults and Children Related to Crop-Growing in Niger. J. Environ. Public Health 2016, 2016, 1-8. [CrossRef] [PubMed]

25. Rutgers, C.; Colon, C.; Thapa, R.R.; Heikens, A.; Gutmann, B.; Biraghi, E.; Buj, V. UNICEF Understanding the Impacts of Pesticides on Children: A Discussion Paper; UNICEF: New York, NY, USA, 2018; pp. 1-26.

26. Carneiro, F.F.; Augusto, L.G.S.; Rigotto, R.M.; Friedrich, K.; Búrigo, A.C. Dossiê ABRASCO: Um Alerta Sobre os Impactos dos Agrotóxicos na Saúde; Expressão Popular: São Paulo, Brasil, 2015; ISBN 978-85-9876-880-9.

27. Negatu, B.; Kromhout, H.; Mekonnen, Y.; Vermeulen, R. Occupational pesticide exposure and respiratory health: A large-scale cross-sectional study in three commercial farming systems in Ethiopia. Thorax 2017, 72, 1-8. [CrossRef]

28. Quansah, R.; Bend, J.R.; Abdul-Rahaman, A.; Armah, F.A.; Luginaah, I.; Essumang, D.K.; Iddi, S.; Chevrier, J.; Cobbina, S.J.; Nketiah-Amponsah, E.; et al. Associations between pesticide use and respiratory symptoms: A cross-sectional study in Southern Ghana. Environ. Res. 2016, 150, 245-254. [CrossRef]

29. Faria, N.M.X.; Facchini, L.A.; Fassa, A.G.; Tomasi, E. Pesticides and respiratory symptoms among farmers. Rev. Saúde Pública 2005, 39, 973-981. [CrossRef]

30. U.N. Human Rights Council Report of the Special Rapporteur on the Right to Food. Rep. Spec. Rapp. Right Food Hilal Elver 2017, 01059, 24.

31. Muñoz-Quezada, M.T.; Lucero, B.A.; Barr, D.B.; Steenland, K.; Levy, K.; Ryan, P.B.; Iglesias, V.; Alvarado, S.; Concha, C.; Rojas, E.; et al. Neurodevelopmental effects in children associated with exposure to organophosphate pesticides: A systematic review. Neurotoxicology 2013, 39, 158-168. [CrossRef] 
32. Froes Asmus, C.I.R.; Camara, V.M.; Landrigan, P.J.; Claudio, L. A Systematic Review of Children's Environmental Health in Brazil. Ann. Glob. Heal. 2016, 82, 132-148. [CrossRef]

33. Van Wendel de Joode, B.; Mora, A.M.; Lindh, C.H.; Hernández-Bonilla, D.; Córdoba, L.; Wesseling, C.; Hoppin, J.A.; Mergler, D. Pesticide exposure and neurodevelopment in children aged 6-9 years from Talamanca, Costa Rica. Cortex 2016, 85, 137-150. [CrossRef] [PubMed]

34. Runkle, J.; Flocks, J.; Economos, J.; Tovar-Aguilar, J.A.; McCauley, L. Occupational risks and pregnancy and infant health outcomes in florida farmworkers. Int. J. Environ. Res. Public Health 2014, 11, 7820-7840. [CrossRef] [PubMed]

35. Gascon, M.; Sunyer, J.; Martínez, D.; Guerra, S.; Lavi, I. Persistent organic pollutants and children ' s respiratory health: The role of cytokines and inflammatory biomarkers. Environ. Int. 2014, 69, 133-140. [CrossRef] [PubMed]

36. Weselak, M.; Arbuckle, T.E.; Wigle, D.T.; Krewski, D. In utero pesticide exposure and childhood morbidity. Environ. Res. 2007, 103, 79-86. [CrossRef] [PubMed]

37. López-Gálvez, N.; Wagoner, R.; Quirós-Alcalá, L.; Van Horne, Y.O.; Furlong, M.; Avila, E.; Beamer, P. Systematic literature review of the take-home route of pesticide exposure via biomonitoring and environmental monitoring. Int. J. Environ. Res. Public Health 2019, 16, 2177. [CrossRef]

38. Dayasiri, K.C.; Jayamanne, S.F.; Jayasinghe, C.Y. Patterns of acute poisoning with pesticides in the paediatric age group. Int. J. Emerg. Med. 2017, 10,1-7. [CrossRef]

39. Tagiyeva, N.; Devereux, G.; Semple, S.; Sherriff, A.; Henderson, J.; Elias, P.; Ayres, J.G. Parental occupation is a risk factor for childhood wheeze and asthma. Eur. Respir. J. 2010, 35, 987-993. [CrossRef]

40. Benka-Coker, W.; Loftus, C.; Karr, C.; Magzamen, S.; Loftus, C.; Karr, C.; Magzamen, S.; Benka-coker, W.; Loftus, C.; Karr, C.; et al. Association of Organophosphate Pesticide Exposure and a Marker of Asthma Morbidity in an Agricultural Community Association of Organophosphate Pesticide Exposure and a Marker of Asthma Morbidity in an Agricultural Community. J. Agromed. 2019, 1, 1-9.

41. Benka-Coker, W.; Loftus, C.; Karr, C.; Magzamen, S. Characterizing the joint effects of pesticide exposure and criteria ambient air pollutants on pediatric asthma morbidity in an agricultural community. Environ. Epidemiol. 2019, 3, e046. [CrossRef]

42. Raanan, R.; Gunier, R.B.; Balmes, J.R.; Beltran, A.J.; Harley, K.G.; Bradman, A.; Eskenazi, B. Elemental sulfur use and associations with pediatric lung function and respiratory symptoms in an agricultural community (California, USA). Environ. Health Perspect. 2017, 125, 1-8. [CrossRef]

43. Gunier, R.B.; Raanan, R.; Castorina, R.; Holland, N.T.; Harley, K.G.; Balmes, J.R.; Fouquette, L.; Eskenazi, B.; Bradman, A. Residential proximity to agricultural fumigant use and respiratory health in 7-year old children. Environ. Res. 2018, 164, 93-99. [CrossRef] [PubMed]

44. Raherison, C.; Baldi, I.; Pouquet, M.; Berteaud, E.; Moesch, C.; Bouvier, G.; Canal-raffin, M. Pesticides Exposure by Air in Vineyard Rural Area and Respiratory Health in Children: A pilot study. Environ. Res. 2019, 169, 189-195. [CrossRef] [PubMed]

45. Duramad, P.; Harley, K.; Lipsett, M.; Bradman, A.; Eskenazi, B.; Holland, N.T.; Tager, I.B. Early environmental exposures and intracellular Th1/Th2 cytokine profiles in 24-month-old children living in an agricultural area. Environ. Health Perspect. 2006, 114, 1916-1922. [CrossRef] [PubMed]

46. Kudagammana, S.T.; Mohotti, K. Environmental exposure to agrochemicals and allergic diseases in preschool children in high grown tea plantations of Sri Lanka. Allergy Asthma Clin. Immunol. 2018, 14, 1-5. [CrossRef]

47. Dallaire, F.; Dewailly, É.; Muckle, G.; Vézina, C.; Jacobson, S.W.; Jacobson, J.L.; Ayotte, P. Acute infections and environmental exposure to organochlorines in Inuit infants from Nunavik. Environ. Health Perspect. 2004, 112, 1359-1364. [CrossRef] [PubMed]

48. Meng, G.; Feng, Y.; Nie, Z.; Wu, X.; Wei, H.; Wu, S. Internal exposure levels of typical POPs and their associations with childhood asthma in Shanghai, China. Environ. Res. 2016, 146, 125-135. [CrossRef]

49. Cupul-Uicab, L.A.; Terrazas-Medina, E.A.; Hernández-Ávila, M.; Longnecker, M.P. Prenatal Exposure to $\mathrm{p}, \mathrm{p}^{\prime}$-DDE and p,p'-DDT in Relation to Lower Respiratory Tract Infections in Boys From a Highly Exposed Area of Mexico. Environ. Res. 2014, 132, 19-23. [CrossRef] 